\title{
Effect of Organic Solvent on Polarographic Diffusion Current of Organic Compound
}

\author{
By \\ Makoto Susuki and Shigeo SAwAdA \\ Department of Chemistry, Faculty of Science and Technology, Kinki University, \\ Kowakae, Higashi-Osaka, Japan
}

(Received Feb. 13, 1971)

\section{Introduction}

It has been so far confirmed experimentally that diffusion current is inversely proportional to the square root of the viscosity of electrolytic solution, as predicted by Stokes-Einstein's and Ilkovic equations, when the viscosity is varied by addition of viscous materials such as glycerine and sucrose. ${ }^{1)}$ It was found, however, that in the case of water-organic solvent mixtures variation of diffusion current with chaging composition of water-organic solvent could not be explained only by variation of solution viscosity, though it varies with composition of the solution. For example, Halle ${ }^{2}$ studied on the variation of the diffusion currents of $\mathrm{T} 1$ (I), Pb (II), and $\mathrm{Cd}$ (II) ions in aqueous solutions of formamide and its $\mathrm{N}$-methyl-substituted derivatives and found that the diffusion current was smaller than that calculated from the viscosity of the solution. Schwabe ${ }^{3)}$ made a similar investigation on organic depolarizers such as phenosafranine and methylene blue in aqueous organic solvent and obtained the results, on the contrary to Hale's finding, that the diffusion current was larger than that expected by viscosity.

The present authors also carried out more detailed experiments about dependence of wave-height (diffusion current) on composition of electrolytic solution with various organic solvents. In this paper some of the results will be reported.

\section{Experimentals}

Among the organic solvents used, dioxane was refluxed with sodium metal for 8 hours, acetonitrile and dimethylformamide (DMF) were sufficiently dried on silica gel and anhydrous potassium carbonate, respectively, and then, they were fractionally distilled with rectifier. For ethanol and other chemicals the special grade reagents were used without further purification.

Mixtures of nitric acid-lithium citrate, acetic acid-lithium acetate, acetic acidpotassium acetate, monochloroacetic acid-potassium acetate, monochloroacetic aicdlithium acetate were used as buffer components to keep $\mathrm{pH}$ of the sodlution constant at any composition of water-organic solvent mixtures. Gelatine solution of $0.01 \%$ was added to the solution for a maximum suppressor if necessary. The concentration of the depolarizer was $0,5 \mathrm{~m} M$ or $1 \mathrm{~m} M$ throughout the work, 
Values of $\mathrm{pH}$ described are the apparent values measured by a glass electrode with Yanagimoto Type A-42 pH meter. Polarographic measurements were made with Yanagimoto Type PA-102 Polarograph and Type GA-103 Galvarecorder. The density of solution was determined with Weld type picnometer and the viscosity of solution with Ostwald viscosimeter.

An aqueous saturated calomel electrode was used as a reference electrode.

\section{Results and Discussion}

The measured relative viscosities of the electrolytic solutions at various compositions of water and an organic solvent are listed in Table I. As the viscosity varies with the solvent content, the diffusion current $I_{d}$ is expected to be inversely proportional to the square root of the solution viscosity, if Stokes' law is held in this case.

At first, at various contents of glycerine in the buffer solution of $\mathrm{pH} 5$ the observed diffusion currents of 0 -nitrobenzoic acid were compared with the values calculated by Stokes-Einstein's and Ilkovic equations for the change of viscosity of the solution. The results are listed in Table II with the measured relative viscosities.*) As shown in

Table I. Relative viscosity of water-organic solvent mixture containing buffer components

\begin{tabular}{|c|c|c|c|c|c|}
\hline $\begin{array}{l}\text { Organic } \\
\text { solvent } \\
(\% \\
\text { in vol. })\end{array}$ & $\mathrm{DMF}^{(1)}$ & Dioxane $e^{(2)}$ & $\begin{array}{l}\text { Aceto- } \\
\text { nitrile }\end{array}$ & Ethanol $^{(4)}$ & $\begin{array}{l}\text { Form- } \\
\qquad \operatorname{amide}^{(5)}\end{array}$ \\
\hline 0 & 1.047 & 1.095 & 1.047 & 1.095 & 1.061 \\
\hline 10 & 1.341 & 1.310 & 1.129 & 1.508 & \\
\hline 20 & 1.645 & 1.558 & 1.137 & 1.926 & 1.188 \\
\hline 30 & 1.964 & 1.794 & 1.062 & 2.363 & \\
\hline 40 & 2.337 & 2.095 & 1.043 & 2.598 & 1.405 \\
\hline 50 & 2.701 & 2.259 & 0.977 & 2.718 & \\
\hline 60 & 2.966 & 2.374 & 0.877 & 2.726 & 1.854 \\
\hline 70 & 2.971 & 2.284 & 0.758 & 2.577 & \\
\hline 80 & 2.340 & 2.001 & 0.629 & 2.223 & 2.463 \\
\hline 90 & 1.533 & 1.539 & 0.501 & 1.818 & \\
\hline 100 & 1.003 & & 0.448 & 1.293 & 3.842 \\
\hline
\end{tabular}

(1) $\mathrm{Up}$ to $40 \% ; 0.1 M$ tetraethylammonium perchlorate $+0.1 M$ acetic acid $+0.1 M$ potassium acetate $(\mathrm{pH}=5)$

40 to $100 \% ; 0.1 M$ tetraethylammonium perchlorate $+0.1 M$ salicylic acid $+0.1 M$ tetraethylammonium salicylate $(\mathrm{pH}=5)$

(2) $0.1 M$ tetraethylammonium bromide $+0.1 M$ acetic acid $+0.1 M$ potassium acetate $(\mathrm{pH}=5)$

(3) $0.1 M$ sodium perchlorate $+0.1 M$ acetic acid $+0.1 M$ potassium acetate $(\mathrm{pH}=5)$

(4) $0.1 M$ tetraethylammonium bromide $+0.1 M$ acetic acid $+0.1 M$ potassium acetate $(\mathrm{pH}=5)$

(5) $0.1 M$ lithium nitrate $+0.1 M$ lithium citrate $+0.1 N$ nitric acid $(\mathrm{pH}=5)$

*) Hereafter, the calculated diffusion current (solid line in the figures) is expressed relative to the observed diffusion current of each depolarizer in 0 or $10 \%$ organic solvent, 
Table II, the observed values coincide approximately with the calculated values. Then, it is concluded that Stokes' law is held in the solution of low glycerine content notwithstanding a wide range of variation in viscosity. But with other organic solvents having low viscosity the experimental results did not agree with the expectation as described below.

Variations of the diffusion currents of nitrobenzene and 0 -nitrobenzoic acid with changing content of DMF (in volume \%) at constant $\mathrm{pH}$ of 5.0 are shown in Fig. 1.

Table II. Observed and calculated values of the diffusion currents of $o$-nitrobenzoic acid in the solutions of various glycerine contents

\begin{tabular}{c|c|c|c}
\hline \multirow{2}{*}{$\begin{array}{c}\text { Glycerine } \\
\text { (\% in volume })\end{array}$} & $\begin{array}{c}\text { Relative } \\
\text { viscosity }\end{array}$ & \multicolumn{2}{|c}{ Diffusion current $(\mu \mathrm{A})$} \\
\cline { 3 - 4 } & Calculated & Observed \\
\hline 0 & 1.061 & 11.96 & 11.96 \\
5 & 1.222 & 11.14 & 11.04 \\
10 & 1.409 & 10.38 & 10.28 \\
15 & 1.636 & 9.64 & 9.54 \\
20 & 1.933 & 8.86 & 8.84 \\
25 & 2.257 & 8.20 & 8.18 \\
30 & 2.679 & 7.53 & 7.33 \\
35 & 3.270 & 6.81 & 6.66 \\
\hline
\end{tabular}

Supporting electrolyte : $0.1 \mathrm{M} \mathrm{LiNO}_{3}$ containing $0.01 \%$ gelatine Concn. of depolarizer : $1 \mathrm{mM}$

Buffer component : $0.1 \mathrm{MLi}$-citrate $+0.1 \mathrm{~N} \mathrm{HNO}_{3}$

Temp. $=25^{\circ} \mathrm{C}, m=1.597 \mathrm{mg} / \mathrm{sec}$.

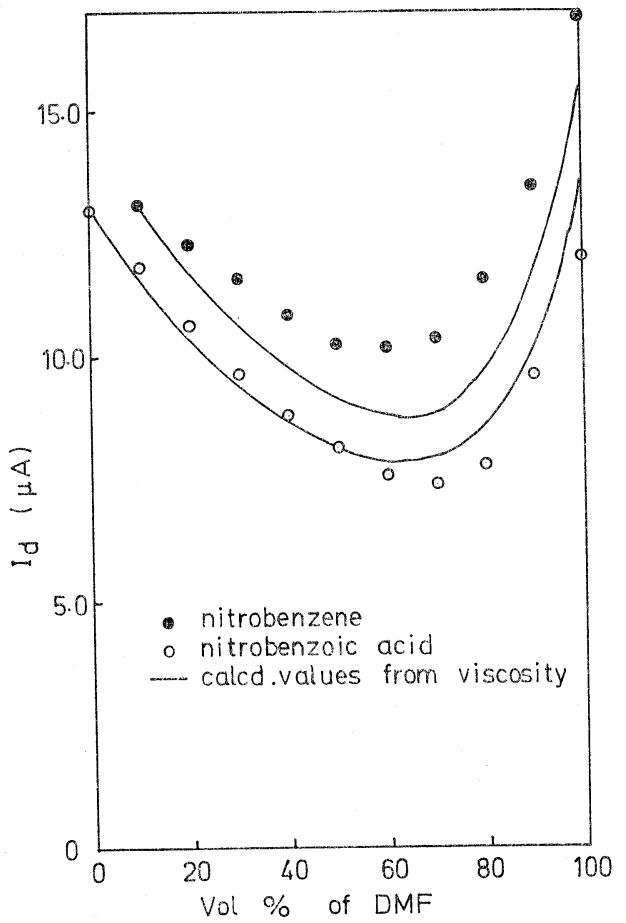

Fig. 1. Variation of diffusion current with content of DMF. $m=1.70 \mathrm{mg} / \mathrm{sec}, p H=5,0, \mathrm{Temp}_{\circ}=35^{\circ} \mathrm{C}$, Concn $_{\mathrm{s}}=1 \mathrm{~m} M$. 
It is seen that the difference in the diffusion currents of the depolarizers, which is not so large in 10\% DMF solution, becomes gradually larger with increasing content of $\mathrm{DMF}$ until the difiusion current of nitrobenzene reaches about 1.4 times as large as that of o-nitrobenzoic acid in 100\% DMF solution. When the content of DMF increases, the diffusion current of nitrobenzene becomes larger than the calculated one, while the diffusion current of $o$-nitrobenzoic acid becomes smaller.

When dioxane was used as an organic solvent, the difference in the diffusion currents of the both depolarizers is larger than that in DMF, and the diffusion current of nitrobenzene amounts to about 1.5 times as large as that of $o$-nitrobenzoic acid in $90 \%$ dioxane (Fig. 2). Relations between the observed and calculated values of the both depolarizers are similar to those in DMF. In this case, however, the diffusion current of 0 -nitrobenzoic acid is significantly smaller than the calculated one. With acetonitrile or ethanol as an organic solvent, the behavior is similar to that with DMF or dioxane (Fig. 3 and 4).

Somewhat different results from the other organic solvents were obtained in the case of formamide as an organic solvent. As shown in Fig. 5, the diffusion current of $o$-nitrobenzoic acid is approximately equal to the calculated one in all percentages of formamide content and the difference in the diffusion currents of the both depolarizers is comparatively small.

From the experimental results with the five organic solvents except with glycerine, it is noticed that the diffusion current of nitrobenzene is in all cases larger than that of $o$-nitrobenzoic acid and the difference in the diffusion currents becomes larger with

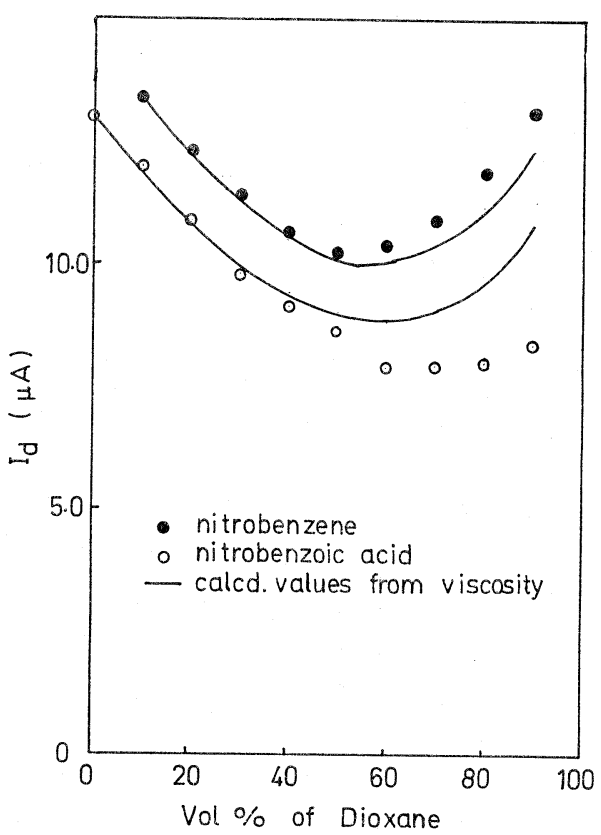

Fig. 2. Variation of diffusion current with content of dioxane

$m=1.70 \mathrm{mg} / \mathrm{sec}$., $p H=5.0$,

Temp. $=25^{\circ} \mathrm{C}$, Goncn, $=1 \mathrm{~m} M_{\text {r }}$

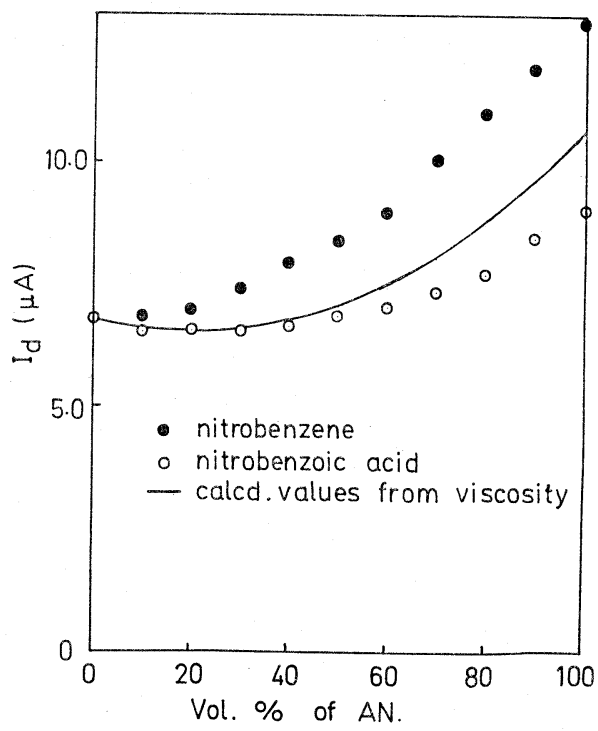

Fig. 3. Variation of diffusion current with content of acetonitrile. $m=1.75 \mathrm{mg} / \mathrm{sec}$, $p H=5.0$, Temp. $=25^{\circ} \mathrm{C}$, Concn $,=0,5 \mathrm{mM}$ 


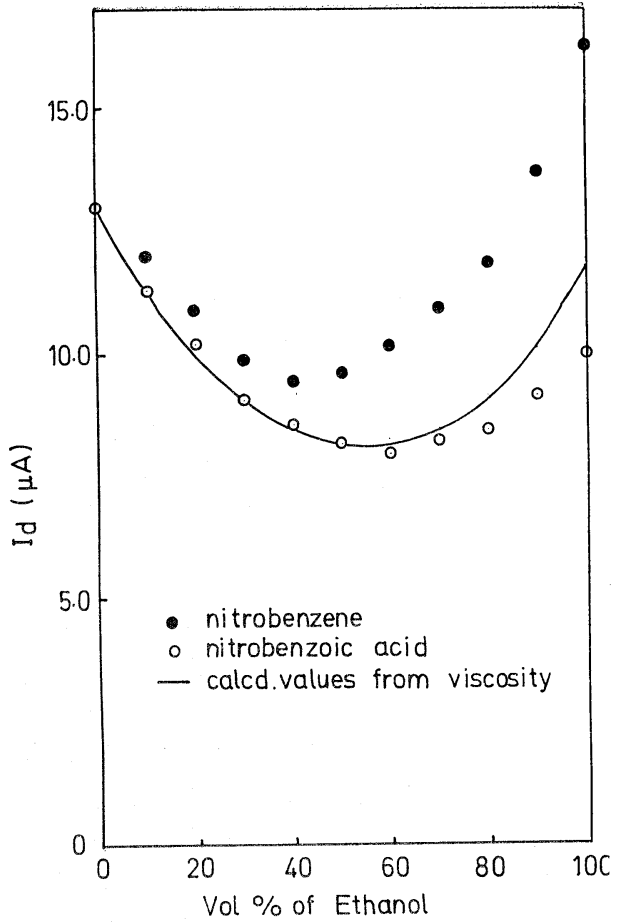

Fig. 4. Variation of diffusion current with content of ethanol $m=1.70 \mathrm{mg} / \mathrm{sec} ., p H=5.0$, Temp. $=25^{\circ} \mathrm{C}$, Goncn. $=1 \mathrm{~m} M$.

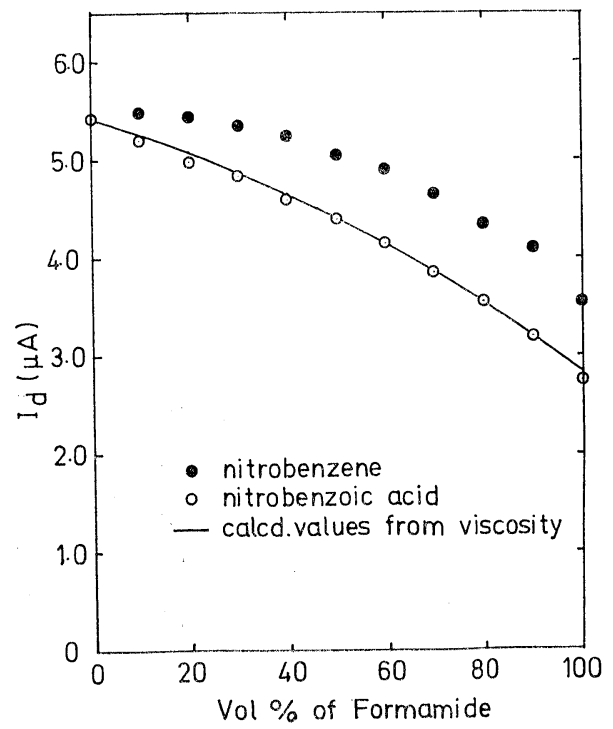

Fig. 5. Variation of diffusion current with content of formamide $m=1.075 \mathrm{mg} / \mathrm{sec}$., $p H=5.0$ Temp. $=25^{\circ} \mathrm{C}$, Concn. $=0.5 \mathrm{~m} M$.

increasing content of organic solvent, though the magnitude of the difference varies with each solvent, and that the observed diffusion current of nitrobenzene is larger than the calculated one, while that of $o$-nitrobenzoic acid is in almost cases smaller than the calculated one.

Since 0 -nitrobenzoic acid exists in an ionic form in the solution of $\mathrm{pH} \mathrm{5.0,} \mathrm{as} \mathrm{its}$ $\mathrm{pK}_{\mathrm{a}}$ is about 2.2, and nitrobenzene exists as a neutral molecule in the same solution, it can be considered that the above phenomena are related to the form of depolarizer in solution, i.e., the effect of organic solvent on the magnitude of polarographic current of organic compounds depends on the form of depolarizer, whether it is in an ionic form or a non-ionic form in the solution.

Validity of the above consideration was confirmed by the following experiments on the behavior of 0 -nitrophenol in water-ethanol solutions of $\mathrm{pH} 4$ and 10 . As $\mathrm{pK}_{\mathrm{a}}$ of 0 -nitrophenol is 7.2, this compound exists in a non-ionic form in the solution of $\mathrm{pH}$ 4 and in an ionic form in the solution of $\mathrm{pH} 10$. The experimental results are shown in Fig. 6. Evidently in the solution of $\mathrm{pH} 4$ the diffusion current of 0 -nitrophenol is larger than that calculated, whereas in $\mathrm{pH} 10$ the relation is reversed in accordance with the above consideration. As for the difference in the diffusion currents of the non-ionic and the ionic forms, comparison of the currents can not be made directly in the figure, because the magnitudes of the both currents differ from one another even in $0 \%$ ethanol solution. The difference of the both currents, however, seems to become 


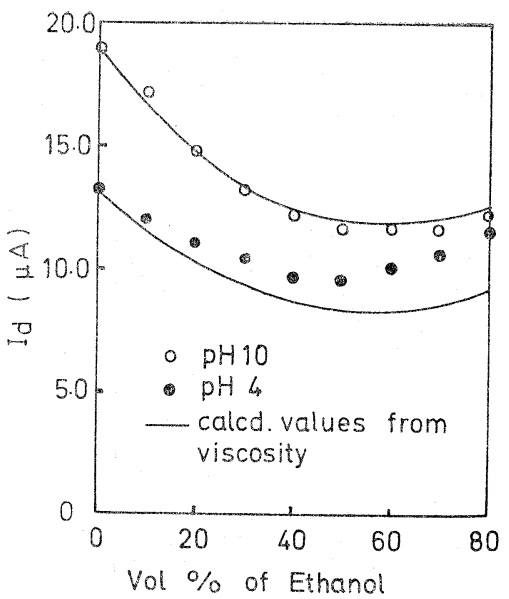

Fig. 6. Variation of diffusion current of $o$-nitrophenol with content of ethanol. $m=1.74 \mathrm{mg} / \mathrm{sec}$., Temp. $=25^{\circ} \mathrm{C}$, Concn. $1 \mathrm{~m}=M$.

larger with increasing content of ethanol, if correction is made for the difference in $0 \%$ ethanol solution to be zero.

It is confirmed from the above results that the observed diffusion currents deviate from the calculated one in the solution of high content of organic solvent. This means that some factors other than viscosity are also operative to the movement of particle in the solution. The main factor responsible for this seems to be a change in diffusion coefficient of the particle. Some authors ${ }^{4}$ pointed out that diffusion coefficient of a neutral molecule differs from that of the dissociated ionic form for some aliphatic acids, e.g., monochloro-acetic acid. But this is not a significant factor in the present case, because the differences of the coefficients found by the above authors are not so large to produce a meaningful difference in diffusion current.

From the standpoint of the electrostatic attraction force it may be reasonable to assume that solvation degree of a neutral molecule in an organic solvent is much less than hydration degree in an aqueous solution. If the assumption is valid, it follows that the moving particle in non-ionic form becomes smaller in size and, accordingly, larger in diffusion current in the solution of high content of organic solvent. From the same reason, for an ion having a strong electric field around it, solvation will occur to some extent and, furthermore, ion-pair formation will become remarkable as the dielectric constant of the solution decreases with increasing content of organic solvent. The size of the moving particle in an ionic form, therefore, becomes larger and the diffusion current becomes smaller.

To compare the behavior of an ionic form of organic compounds with that of metal ion, variation of the diffusion currents of $\mathrm{T} 1$ (I), and $\mathrm{Cd}$ (II) in water-DMF mixtures with changing content of DMF was measured. The results are shown in Fig. 7. It is seen that observed current is lower than the calculated one in a similar manner to that for organic ions, although the ionic charge is opposite to the organic ions investi-

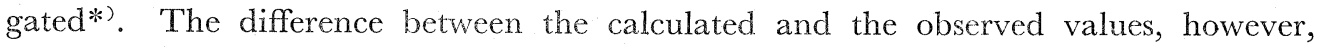

*) Though the above described behavior of the ionic form of organic compounds was experimentally limited to the acid anion, the similar behavior was found also for a base cation in the experiment with nitroanilinium cation in water-organic solvent mixtures of $\mathrm{pH} 1$. 
is much larger than that for organic ion. This seems to be caused also by the difference in size of the moving particles, which results from the degree of solvation and ionpair formation by an electrostatic force, since the size and the charge distribution of metal ion differ considerably from those of organic ion. At present, however, further discussion on the degree of solvation and hydration can not be made, since the selective solvation of ions in water-organic solvent mixtures is not precisely $\mathrm{known}^{5}$.

Finally, the effect of organic solvent was examined with neutral red as a depolarizer. Since $\mathrm{pK}_{\mathrm{a}}$ of neutral red is about 6.8, this compound exists in a cationic form in the buffer solution of $\mathrm{pH}$ 4. When DMF is added to the solution, therefore, behavior of the diffusion current of neutral red is expected to have a similar tendency to that of 0 -nitrobenzoic acid. But, as shown in Fig. 8, the experimental results deviated remarkably from the expectation. On the contrary to the behavior of $o$-nitrobenzoic acid, the observed current is always higher than the calculated one and a large deviation from the calculated value occurs already in a solution of low DMF content, such as $10 \%$ DMF. The pattern of variation of the current with changing content of DMF is also different from those of the other organic depolarizers investigated. Similar behavior was observed with dioxane or acetonitrile as an organic solvent.

This anomalous behavior can not be explained precisely at present, but this may suggest that neutral red molecules probably associate with each other in aqueous solution and dissociate gradually with increasing content of organic solvent.

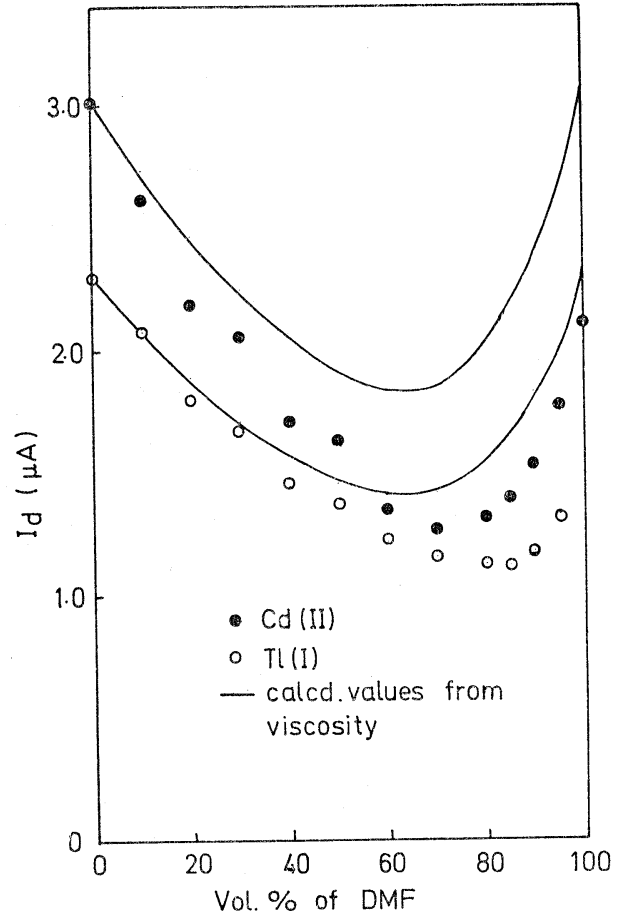

Fig. 7. Variation of diffusion current of metal ions with content of DMF $m=1.315 \mathrm{mg} / \mathrm{sec}$., Temp. $=25^{\circ} \mathrm{C}$ Concn. $=0.5 \mathrm{~m} M$.

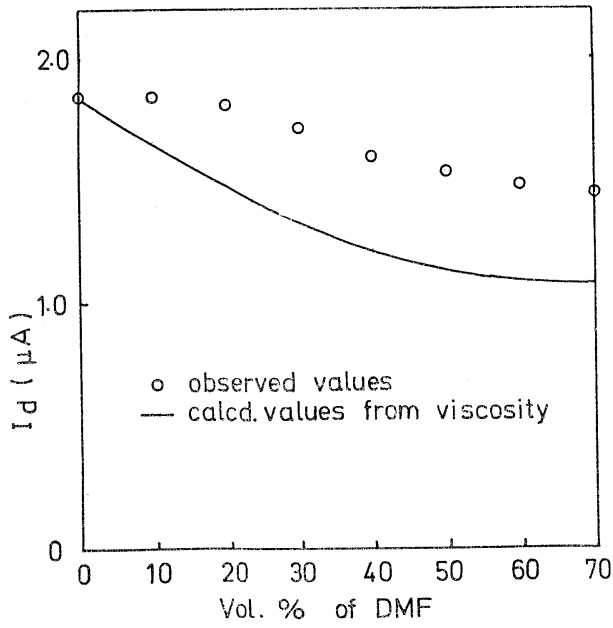

Fig. 8. Variation of diffusion current of neutral red with content of DMF $m=2.145 \mathrm{mg} / \mathrm{sec}$, $p H=4.0$, Temp. $=25^{\circ} \mathrm{C}$, Concn.$=0.5 \mathrm{~m} M$. 


\section{Conclusion}

From the results described above, it is concluded that (i) the observed diffusion current of a non-ionic form is larger than the calculated one, whereas that of an ionic form is smaller, (ii) the difference in the diffusion currents between non-ionic and ionic forms becomes larger with increasing content of organic solvent in the solution.

The phenomena may be explained by the variation in size of the moving particle caused by changing degrees of hydration, solvation and ion-pair formation with increasing content of organic solvent.

\section{Acknowledgment}

The authors wish to thank Messrs. S. Ueno and A. Nakanishi for their assistance in the experimental work.

\section{References}

1) I.M. Kolthoff and J.J. Lingane : Polarogradhy, 2nd Ed. Vol. 1, p. 97, 1952.

2) J.M. Hale and R. Parsons : Advances in Polarography, Vol. 3, p. 829, 1960.

3) K. Schwabe : Progress in Polarography, Vol. 1, p. 333, 1962.

4) R.A. Robinson and R.H. Stokes : Electrolyte Solutions, 2nd Ed. p. 302, 1959.

C.W. Garland, S. Tong and W.H. Stockmayer : J. Phys. Chem., 69, 2469 (1965).

5) H. Schneider : Solute-Solvent Interactions, ed. by J.F. Coetzee and C.D. Ritchie, p. 301, 1969.

有機化合物のポーラログラフ拡散電流におよぼす有機溶媒の影響

鈴 木 信, 澤田恵夫 (近畿大学理工学部化学教室)

水一有機混合溶媒中での有機化合物の抾散電流は溶 媒の組成比が変化するに従って，溶媒の粘度の平方根 飞逆比例して変化するよりも大きいものあるいは小さ いもの等種々様々であり, 有機溶媒の種類によっても 変る。一般に, 二トロ安息香酸のように, 溶液中で解 離してイオンとして溶存するような有機化合物は溶桇 の粘度から予想される值に一致するか, 少し低くなる が, ニトロベンゼンのような中性の分子として溶存す

\begin{abstract}
るような有機化合物では粘度から予想たれる值より高 くなるという結果を得た。てのような結果は溶媒組成 の変化によって水和，溶媒和の程度が変るため，およ びイオン会合が生じやずくなるためであろうと考えら れる、しかしながら、ニュートラル・レッドでは更に 複雑な変化が生じた。乙れは純水溶媒中では会合のよ らなものが生じているためであろうと推測した。
\end{abstract}

